\title{
Transformational Potential of Blended Learning to Personalize Foreign Language Teaching in a Non-Linguistic Higher School
}

\author{
Dinara G. Vasbieva - Irina I. Klimova
}

DOI: 10.18355/XL.2015.08.01.2-10

\begin{abstract}
The article investigates the importance of personalization of teaching a foreign language in a non-linguistic higher school through blended learning. The important role of dynamic syllabus, information and communication technology and electronic language portfolio is examined and analysed. The authors come to the conclusion that blended learning is a new educational model with great potential to increase students' outcomes and create exciting new roles for teachers.
\end{abstract}

Key words

blended learning, foreign language teaching, electronic language portfolio, information and communication technology, dynamic syllabus

\section{Introduction}

The model of a university graduate is understood as a conceptual description of learning goals, learning content and the principles of organizing the educational process in undergraduate programs. One of the major objectives of modern educational system is developing personal intellectual abilities, critical thinking skills essential for university studies across disciplines and independent learning strategies. Skills of self-study, willingness and ability to adapt to ever-changing social and economic situations are very important for modern graduates (http://www.consultant. ru/law/). Federal target program on education for 2011-2015 is aimed at ensuring accessibility of high-quality education to satisfy the requirements of innovative socialoriented development of the Russian Federation.

Solving these problems involves extending the teaching environment and creating virtual classrooms through online and blended learning related to students' cognitive needs, interests and abilities. Centred on purposeful, real-life objectives universities are working to get closer to the golden ideal of every student getting exactly what they need, when they need it. It is also very important to ensure learnercentered approach in the context of generality of educational environment (Sazonov, 2011).

\section{A student-centred approach in the Russian educational system}

The necessity of modernization and globalization of the Russian educational system has been dictated by the country's integration into a common educational space within the framework of Russia's accession to the Bologna process. One of the major driving forces and basic motivations of this process is global competition in the field of higher education. Globalization, in which people, ideas and information are moving freely across national borders, has changed the modern labor market requirements for specialists in various industries. Global changes in the information, communication, professional and other spheres have determined qualitatively new areas of the educational system. Therefore the goal is increasing the international competitiveness of the Russian system of higher training where language teaching focuses on the development of foreign language competence in accordance with the individual value priorities (Vasbieva, 2014 (1):16).

The contemporary educational system in Russia is built on the remains of the old Soviet mechanism, which does not always reflect the tendencies of the modern 
world. The main difference between the old Soviet system and the contemporary one is the approach to programme implementation at schools and universities across the country. The old system set the same standards for all schools and universities, implemented a uniform educational programme for each subject and concentrated on providing students with very thorough and comprehensive knowledge of a wide variety of disciplines.

The problems of contemporary educational system in Russia are much discussed by Russian philosophers, sociologists, psychologists and educators. The traditional model of education is just a transmission of culture and isolated knowledge. In this educational environment a student is not considered to be an active participant of the educational process, but an educand.

There is a need in transition to pedagogy of the integrated personality. This requires, above all, a new look at the individual as a subject of the pedagogical process, mutual partnership of the participants of the educational process and an emphasis on the student's self-reliance, self-development and reflection.

In our opinion, the main obstacles in teaching a foreign language are its methodologies which are time-consuming and require resources, but do not increase the value of foreign language teaching as well as educational services. Generally speaking, classroom assignments do not require students to fully exploit their knowledge and skills or there is irrelevance of students' skills and abilities (for example, advanced students get bored and tune out as the tasks are designed for education's middle-of-the-class mediocrity). The student-centred approach to foreign language teaching aims to identify, analyze and remove all the obstacles in teaching process.

The issue of personalization of educational process has attracted scientists' attention for a long time and a lot of measures have been taken to solve this problem. Active discussions are taking place on accelerating the introduction and integration of information and communication technologies into education (Rotberg, 2010). ICT is known to be a great source to any conventional classroom, especially when used properly and could be an asset to the foreign language classroom (Klimova, 2012). Development of information and communication technologies (ICT) gives an opportunity to put personalization into practice through high-quality blended learning models.

\section{Blended Learning}

New types of learning activities challenge our thinking as to how learning might be facilitated, creating new etiquettes of learning and teaching, and shifting the locus of control from the teacher to the learner (Littlejohn - Pegler, 2007).

Blended learning is an approach to learning and teaching which combines and aligns learning undertaken in face-to-face sessions with learning opportunities created online. It is a new educational model with great potential to increase students' outcomes and create exciting new roles for teachers (Klimova, 2009).

A Blended learning approach is one, which in most cases, will enhance and extend the learning opportunities for our 21st Century learners. The JISC study (http://www.jisc.ac.uk/media/documents/programmes/elearningpedagogy/iotext.doc) describes what uses and expectations learners have for learning and teaching with technology.

Blended learning is a blanket term for an approach, and the University sees that the following types of blend will be most useful in providing a complete learning environment for our students. These are:

- full provision of module related documents in electronic format

- regular formative assessment with feedback 
- $\quad$ opportunities to learn from each other collaboratively

- $\quad$ electronic personal development planning

- the opportunity to submit all appropriate summative assessments electronically

- $\quad$ interactive face to face learning

The rationale for supporting each of these perspectives on blended learning is that every learner is able to:

- $\quad$ have 24/7 access to all learning content, and to ensure equality of access;

- gauge their progress against the learning outcomes, to receive supporting feedback on this progress, and for the educator to have information on students' progress;

- $\quad$ participate in, and engage with interactive learning opportunities in her or his face-to-face learning sessions. There is no expectation that this need necessarily involves the use of technologies;

- use asynchronous collaborative learning which extends the face to face learning, creating supportive learning networks, managed by learners at a time and place best suited to their needs;

- understand better her or his learning process, act on feedback, so as to become more effective and successful, as well as collecting evidence on achievement to enhance the learners employability;

- $\quad$ save time and paper, and provide feedback quickly to each learner.

In many countries blended learning as a form of education is being developed now. Blended learning is a combination of face-to-face instruction and distance learning. Both forms of learning have their own advantages and disadvantages.

Blended learning tries to take advantages of these two forms. There is no unified system of blended learning and some universities and researchers develop their own models.

The dynamic syllabus (DS) is used more and more often to organize these kinds of learning activities. DS is a multimedia hypertext that allows referring to a large amount of information, including video, audio and graphics. An instructor can use various platforms which do not require any special technical skills. DS consists of the following parts:

- $\quad$ informative module (material to study, questions, tasks, texts);

- $\quad$ meta-information module (hyperlinks);

- $\quad$ communicative module (chats, blogs, forums, e-mails);

- $\quad$ illustrating module (students' web-projects, samples of the best works);

- $\quad$ estimation module (self-tests).

DS has the following advantages in comparison with traditional printed books:

- availability of new and authentic information;

- $\quad$ opportunity to provide students with excessive information;

- $\quad$ use of creative and research tasks;

- $\quad$ organization of autonomous and independent learning;

- interactive tools;

- $\quad$ option to adapt DS to the needs, abilities and interests of particular groups of students.

DS has been developed to provide a database that specifies in detail the learning content. It is a database that evolves as module teams develop the taught content and directed learning opportunities in response to contemporary policy directives, evidence, research findings, narrative and theoretical perspectives. Its role is to allow for the curriculum to be transparent on a continuous basis. It makes explicit the ways in which professional knowledge, skills and attitudes and underpinning subjects are 
developed through the academic levels of the programme. The dynamic syllabus identifies the links and relationships between elements of the curriculum and it provides the opportunity for a holistic approach to curriculum development.

Teaching and learning methodologies are also made explicit within the dynamic syllabus. This will lead the pedagogical evidence-base to come into sharper focus and become more prominent in the process of curriculum development.

The assessment strategy is an important part of the dynamic syllabus. The relevance of the range of assessment modes can be examined in the context of the teaching and learning opportunities provided at any given time. This will help ensure that on-going developments with the assessment strategy enhances the integration of assessments, increases the role of assessment in learning and the effectiveness of assessment in measuring achievement and competence.

To ensure the dynamic nature of the syllabus, module leaders will update the dynamic syllabus on an annual basis in relation to:

- The taught and directed learning content

- Teaching methods and learning activities and their evidence-base

- The assessment strategy: formative assessment methods, focus or mode of summative assessments.

It is good practice for a review of module content, delivery and assessment to take place following evaluation from each group of students.

With the rapidly increasing popularity of the Internet in recent years, the diversity of learning programs continue to shift and change according to the demands of society. Nevertheless, since the development of communicative skills, language learning requires social interaction between the teacher and the students and among the students themselves, the use of computers has for a long time been regarded only as a support tool with regard to certain skill areas (Brandl, 2005).

However, with the advent of multimedia computing and the Internet, the role of computers in language instruction has now become an important issue confronting large numbers of language teachers throughout the world (Warschauer Healey, 1998).

The Information and Communication Technology (ICT) in teaching foreign languages are of increasing interest to both students and teachers.

ICT can be defined as the use of information in order to meet human need or purpose including reference to the use of contemporary devices such as the Internet.

ICT provides a variety of different approaches as well as learning styles that reinforce the material delivered in other formats. Enjoyment is very much a part of effective learning, thereby captivating learners' interest, increasing personal discovery, generating enthusiasm and the desire to learn thereby instilling an interest from within to improve the learners' motivation. ICT both supports and integrates literacy skills. It enhances interactive teaching and learning styles and provides many opportunities for creativity. When used imaginatively it can stimulate curiosity about how languages work, raise the level of cognitive challenge (Ghasemi - Hashemi, 2011).

Students enjoy working with ICT which helps develop their language skills. Using ICT attracts their attention because it is challenging, yet it is apart of their everyday lives. Nevertheless, when students use ICT in the class the “... undeniable improvement of language skills and strategies related to handling information and the language through which it is conveyed in the stages of searching, analyzing and processing information", (Lanni, 2001) when mixed together along with other skills students are benefited and gain much more than what was expected. Nevertheless, due to the students' simultaneous, natural and often incidental acquisition of IT skills, that are needed in order to manage hardware and software so that various tasks are completed and problems are solved. 
By integrating basic IT skills in the classroom, teachers are developing language skills and equipping learners with technology skills. The applications of these technology skills go beyond classroom into the workplace and/or subject specific studies at colleges and universities.

ICT is known to be a valuable asset to the foreign language classroom. For example Market Leader course used at Financial University under the Government of RF (Moscow) includes MyEnglishLab which is a flexible online tool that enriches learning, informs teaching and enhances the course. MyEnglishLab for Market Leader gives teachers instant access to a range of diagnostic tools. In addition, the teacher can assign tasks to the whole class, groups of students, or individual students to help them reach their goals more effectively. The communication tools provided enable the teacher to send messages to his/her students and sometimes, keep in contact outside of class (Vasbieva, 2014 (2): 79).

E-learning seems to be attractive as it implies training using interactive electronic information delivery, including technology applications and processes such as audio or video tape, satellite TV, CD-ROM, and computer-based learning, as well as local intranet/extranet and web-based learning. The application of e-learning have plenty of opportunities in conventional learning environment. The most popular educational facilities are hypertext associated with a system of cross-references in the text arrays of information and multimedia tools for recording and transmission of audio and video files. Multimedia means that computer information can be represented through audio, video, and animation in addition to traditional media (i.e., text, graphics drawings, images). A multimedia application is an application which uses a collection of multiple media sources e.g. text, graphics, images, sound/audio, animation and/or video. Hypermedia can be considered as one of the multimedia applications. Hypermedia is not constrained to be text-based. It can include other media, e.g., graphics, images, and especially the continuous media - sound and video. A foreign language teacher can develop students' listening and speaking skills using the following podcasts:

- hypermedia that allows to combine hypertext and multimedia;

- CD-ROM technology that allows you to store information in the form of text, video, audio and graphic files. It is widely used as an application to modern multimedia course books which provide students with additional assignments for reading, listening, working with vocabulary and grammar;

- wiki technology, a piece of server software that allows users to freely create websites of different content and purpose.

Today, foreign language teachers are given every opportunity to use multimedia, testing programs, electronic libraries, dictionaries, text and video glosses in teaching students professionally oriented vocabulary and telecommunication technologies providing an opportunity to participate in the dialogue of cultures through audio and video conferences.

E-learning shells combining the benefits of most technologies within a single resource and designed on the basis of Moodle, eFront and other platforms allow to make standard course material available in the e-book format, audio, video, image files, hyperlinks as well as to test students' knowledge through a variety of tests. «There is a strong community of developers and programmers who are working to simplify the interface on the one hand while enabling a higher degree of integration with other platforms and programs on the other. For «newbie» educators, this support network is of great assisstance (Kingsley - Wankel, 2009: 4). The experts in the field of computer linguistics note the following advantages of the use of ICT in education: 
- individualization of the learning process;

- learning mobility (feedback, including consultation through e-mails at any time convenient to the teacher and student);

- the use of authentic material in teaching (authentic text, audio and video resources);

- the availability and variety of teaching material;

- a variety of approaches and methodologies;

- interactive and convenient teaching process.

With the help of some technologies you can achieve the successful development of the students' particular language skills. For example, the regular use of blogs or a simple text editor promotes writing skills, and CD-ROM helps to optimize the formation of lexical and grammatical skills. (Dudeney - Hockley, 2007)

In our opinion, to optimize the teaching process it is necessary to create a Student's Electronic Porfolio, which enables to see students' work in a more complete form at the expense of the use of the text, image, audio and video files; to store, edit and display the students' work as well as provide quick access to the electronic portfolio.

To keep a progress record of your contact with each student, it is necessary to create a separate electronic folder, e.g., in Word.Doc. Such a folder contains also all his/her weekly assignment. The teacher can make comments at the beginning, within, and at the end for student to make any necessary corrections. The student may get any suggestion for further work to be done. Comments should be made in color or bold font and then saving it back to the folder. An e-mail enclosing the folder should be sent to the student the week before the midterm and the final examinations. This provides a rubric for the students so they review and know their own progress and learning from their past mistakes. The contents of the folder also are beneficial to the teacher when it comes to overall course grading. Having such a portfolio provides students with the evidence of how well they have performed by the end of semester.

E-learning has great potential in the language classroom, but its effectiveness in practice depends to a large extent on the way it is exploited by teachers and students. The general methodology is also important. The teachers must be certain how to achieve it. Clearly, if they do not set their sights high, they could fall significantly short of their goals.

On the other hand, it is worth arranging face-to-face classes for students who have just begun to study a foreign language. Face-to face instructions can also be used for, summarizing lectures, midterm assessments and examinations, work results presentation and tutorials to help students who need extra support.

Blended learning model of teaching a foreign language to students of nonlinguistic higher schools can be presented in the following scheme (Fig.1):

\begin{tabular}{|c|c|}
\hline \multicolumn{2}{|c|}{ Learning process } \\
\hline Face-to-face instruction & Distance learning \\
\hline Extra review & Study of theoretical material \\
\hline Practical classes (for beginners) & Video and audio lessons \\
\hline Tutorials & Project and research activities \\
\hline Examinations & Chats, blogs, etc. \\
\hline & Individual tasks \\
\hline
\end{tabular}

Figure 1 Blended learning model of teaching a foreign language to students of nonlinguistic higher schools 


\section{A changing relationship}

Thus a process of integration of personal tools and technologies is occurring, which introduces both benefits and risks. This is likely to be reinforced by oncoming generations - Prensky's 'digital natives' (http://tinyurl.com/ypgvf). Yet students' preferences are largely unrecognised within their universities, where the need for skills development in effective e-learning strategies is often underestimated and access on campus to technologies of their choice restricted.

For most students, the university still remains the central focus of their learning. There is little to suggest that students' use of personal technologies has replaced university provision entirely - rather that the greater diversity of options now available to them enables learners to become more efficient in their use of time, more flexible in how and where they study, and more wide ranging in their use of resources.

Nonetheless, personal technologies and social networking are emerging issues in e-learning, requiring greater flexibility and diversity in institutional policies and provision, combined with an increased focus on skills development for learners in the benefits and the pitfalls of their choices.

Rather than acting as supervisors of learning, universities - as illustrated in Figure 2 - may increasingly become providers of services, offering the infrastructure and opportunities for skills development to support appropriate and effective elearning based on a wider range of options.

\begin{tabular}{|c|c|c|}
\hline \multicolumn{3}{|c|}{ Increasing students' autonomy } \\
\hline $\begin{array}{l}\text { The University monitors } \\
\text { students' access to } \\
\text { information through on- } \\
\text { campus IT centres }\end{array}$ & $\begin{array}{l}\text { Students use a wide range } \\
\text { of technologies in their } \\
\text { personal lives, but the } \\
\text { value of these in formal } \\
\text { learning is less well } \\
\text { recognised }\end{array}$ & $\begin{array}{l}\text { Students have access to their own } \\
\text { choice of software and } \\
\text { communication tools from } \\
\text { enrolment and are assisted in } \\
\text { adapting and personalising these }\end{array}$ \\
\hline $\begin{array}{l}\text { The University blocks } \\
\text { access to inappropriate } \\
\text { websites and tools not } \\
\text { associated with formal } \\
\text { learning }\end{array}$ & $\begin{array}{l}\text { The University promotes } \\
\text { the use of a VLE, } \\
\text { availability of course } \\
\text { materials } \\
\text { inconsistent }\end{array}$ & $\begin{array}{l}\text { Students have access to multiple } \\
\text { online communities for networked } \\
\text { learning }\end{array}$ \\
\hline $\begin{array}{l}\text { Students enter into } \\
\text { appropriate use agreements } \\
\text { with the University. As a } \\
\text { penalty for misuse, they lose } \\
\text { their right to log on to the } \\
\text { network } \\
\text { Not all students have access } \\
\text { on and off campus to } \\
\text { learning resources on the } \\
\text { network/virtual learning } \\
\text { environment (VLE) }\end{array}$ & $\begin{array}{l}\text { Portable technologies and } \\
24 / 7 \text { access to learning } \\
\text { resources on the } \\
\text { network/VLE enable } \\
\text { learning to take place in } \\
\text { multiple locations } \\
\text { The University enables } \\
\text { access to some social } \\
\text { software by learners and } \\
\text { staff, where required } \\
\text { Students use e-portfolios, } \\
\text { but access to these from } \\
\text { outside the University, } \\
\text { their storage and } \\
\text { ownership often remain } \\
\text { unresolved issues }\end{array}$ & $\begin{array}{l}\text { Students explore their identities } \\
\text { and develop skills through use of } \\
\text { social software, virtual worlds and } \\
\text { simulations } \\
\text { The University provides highly } \\
\text { resourced physical spaces, } \\
\text { managed by educators and } \\
\text { students, for collaborative, } \\
\text { networked learning } \\
\text { The University enables students to } \\
\text { understand the risks and } \\
\text { advantages in learning in a } \\
\text { technology-rich environment and } \\
\text { actively promotes skills of } \\
\text { effective, safe and appropriate } \\
\text { digital learning }\end{array}$ \\
\hline \multicolumn{3}{|c|}{ Increasing university control } \\
\hline
\end{tabular}

Figure 2 Changing relationship between the University and students 


\section{Conclusion}

In conclusion, blended learning is a new educational model with great potential to increase students' outcomes and create exciting new roles for teachers. The unique fully flexible approach to blended learning means that every Unit or lesson can be completed either in class with the Student's Book, or online as selfstudy or a combination of the two. The contemporary digital tools help foreign language teachers to personalize teaching. They ensure the teachers are making the most of the technology their students have come to expect, while joining up self-study and face-to-face course elements into a seamless process.

\section{References}

BRANDL, K. 2005. Are you ready to "MOODLE"? Language Learning \& Technology, Volume 9, Number 2, May 2005, pp.16-23.

DUDENEY G. - HOCKLEY N. 2008. How to teach English with Technology. 3rd impression, Pearson Longman. ISBN 978-1-405-85308-8

GHASEMI, B. - HASHEMI, M. 2011. ICT: Newwave in English language learning/teaching. Procedia-Social and Behavioral Sciences, 15, pp. 3098-3102.

IN THEIR OWN WORDS. [online] Available on the internet: <http://www. jisc.ac.uk/media/documents/programmes/ elearningpedagogy/iotext.doc >.

KINGSLEY, J. - WANKEL, Ch. 2009. Higher Education in Virtual Worlds: Teaching and Learning in Second Life. Emerald Group Publishing Limited. ISBN 978-1-84950-609-0

KLIMOVA I.I. 2009. Blended Learning as a Contemporary Model of Foreign Language Teaching in a Non-Linguistic Higher School. Proceedings of Interacademic Research and Practice Conference "Key Skills and Knowledge Students Need to Participate Successfully in the $21^{\text {st }}$ century Society". Academy of Budget and Treasury. Moscow, pp.142-149.

KLIMOVA I.I. 2012. The Usage of IT in Foreign Language Teaching. Proceedings of Interacademic Research and Practice Conference "What Future Business People Need To Be Successful and Competitive in the $21^{\text {st }}$ century Society". State University of Ministry of Finance of RF. Moscow, pp.121-127.

LANNI, D. 2001. The Rationale: ICT In Language Teaching In 6 Points. [Online] [cit. 12. 8. 2008]. Available on the internet: <http://www.itiscannizzaro.net/Ianni/ articles/rationale.htm>.

LITTLEJOHN, A.H. - PEGLER, C. 2007. Planning for blended learning, Routledge, London ISBN 978-0-415-40361-0.

"ON CONCEPT OF FEDERAL TARGET PROGRAM ON EDUCATION FOR 2011-2015", Order N163-p, February 07, 2011. Available on the internet: <http://www.consultant.ru/law/>.

ROTBERG, I.C. 2010 Balancing Change and Tradition in Global Education Reform/edited by Iris C. Rotberg - 2nd ed. Rowman \& Littlefield Education. ISBN 978-1-60709-502-6 (electronic)

SAZONOV, B.A. 2011. Learner-centered organization of educational process as a condition of higher education modernization. Higher education in Russia, N4, pp.1024.

PRENSKY, M. 2001. Digital Natives, Digital Immigrants, On the Horizon. NCB University Press, Vol. 9 No. 5, October 2001. Available on the internet: $<$ http://tinyurl.com/ypgvf $>$.

VASBIEVA, D.G. 2014 (1). Introduction of a Lean Approach To ProfessionallyOriented Language Teaching.//Science Review: Humanities Research. Scientific Journal. №5. ISSN 2226-0234, pp. 16-22.

VASBIEVA, D.G. 2014 (2). A Lean Approach as a Means of Achieving 
Communicative Competence. XLinguae Journal, Volume 7 Issue 4, October 2014, ISSN 1337-8384, pp.75-82.

WARSCHAUER, M. - HEALEY, D. 1998. Computers and language learning: An overview Language Teaching, 31, pp. 57-71.

Words: 4010

Characters: 27591 (15,33 standard pages)

Assoc. Prof. Dinara Giniyatullovna Vasbieva, PhD

Department "Foreign Languages - 4"

Financial University under the Government of the Russian Federation

Leningradsky prospect 49

125993 Moscow

Russia

dinara-va@list.ru

Assoc. Prof. Irina Iosifovna Klimova, PhD

Department "Foreign Languages - 4"

Financial University under the Government of the Russian Federation Leningradsky prospect 49

125993 Moscow

Russia

iiklimova@mail.ru 